\title{
Chronological Overview of Islamic Vocabulary in the Dictionaries of Albanian Language
}

\author{
Doç. Dr. Lindita Xhanarı (Latıfı) \\ University of Tirana, Faculty of History and Philology, \\ Linguistics Department, email.:lindalatifi@yahoo.com \\ Doç. Dr. Kledi Satka (Sheganı) \\ University of Tirana, Faculty of History and Philology, \\ Linguistics Department, email: shegani@yahoo.com
}

\section{Doi:10.5901/jesr.2014.v4n2p77}

\begin{abstract}
The Islamic terminology in the Albanian language has its origins very early, since about 500 years ago, a time that coincides with the start of the process of Islamization of the Balkans. Islam, Islamic culture and traditions brought by the Ottomans, brought a new style of living and were accepted by most of the Albanians, in all their lands (today: Albania, Kosovo, Macedonia and Montenegro). This process was accompanied by borrowing the Islamic terminology, which since five centuries returned to a natural ingredient of the Albanian language. This terminology, which found itself within the Albanian vocabulary, presents some interesting features, for the way it was adopted to the lexical and grammatical features of the Albanian language. Since in the beginnings, the Albanians were familiarized with its use, but due to the historical circumstances, the use of this terminology had its ups and downs. In this paper, we will try to give a complete picture of the use and misuse of this terminology in a chronological sequence. For this, we have observed how this terminology is presented in the greatest lexicographic works of the Albanian language. This study is divided into four (3) parts: 1.Islamic terminology in the documents before the written Albanian language (X-XIXcentury) 2.Islamic terminology in the dictionaries in the communist period (19441991) 3.Islamic terminology in the Albanian dictionaries after democracy (1992-2013)
\end{abstract}

Keywords: terminology, dictionaries, Islamic, chronological

\section{Introduction}

Albanian Islamic terminology has its origins very early, since about 500 years ago, a time that coincides with the start of the process of Islamization of the Balkans. Islamization, Islamic culture and traditions introduced by the Ottomans, brought a new style of living and were accepted by the majority of the Albanians, in all their territories (today: Albania, Kosovo, Macedonia and Montenegro). The process of incorporation of the Turkish-Oriental borrowings, which lasted for nearly five centuries, emerges as a colorful artwork, that interlocks historical, cultural, ethnographic, linguistic and literature issues. This is not simply a borrowing of words and their meanings in the language that they were introduced. Initially the Albanian language, due to historical circumstances explained earlier, generally borrowed words that express meanings of concepts previously unknown to it. This happens in all languages. Later, these words were accepted and have been embraced in mass, because they were used intensely in the social and administrative everyday life. Once admitted, used and adopted, the Turkish-Oriental borrowings also began to be elaborated into the Albanian language. This is a chain reaction, which continued for a very long time. This process was accompanied by borrowing the religious Islamic terminology, which throughout five centuries was transformed to the main factor of the Albanian language. This terminology, which found itself within the Albanian vocabulary, presents some interesting features, for the way it adopted the lexical and grammatical aspects of the Albanian language. "Islamic Lexicon in the Albanian language is very broad; it is among the oldest oriental borrowings; is among the most stable, because the very nature of religion is stable." 1

Since early the Albanians were familiarized with its use, due to historical circumstances, the use of this terminology had its ups and downs. "Terminology is one of the most complex areas in all fields of knowledge and this is a known fact. Except that, the religious terminology interlocks additional difficulties, especially at a time when a nation has

\footnotetext{
${ }^{1}$ Mehdi Polisi, The Islamic Lexicon integral part of the Albanian vocabulary, Terminology Islamic Academy of Sciences and Arts of Kosovo, Pristina, 2006, p. 89.
} 
different religions, such as the Albanian people. And it's not just the fact that in different religions come different influences from religious sciences in the languages, let us call them the source or major factor, but also for the fact that traditions are not the same among different religions and because, in addition to direct impacts, many terms have been translated through another language, like it had happened, for instance, with some Islamic religious terms, that have entered in the Albanian language from Turkish language." 2

To properly address the depth of this issue, it should be taken into account that the use of Islamic terminology by the Albanians has had three basic problems:

The separation of the Albanian nation in about a century in different Balkan countries.

The existence between Albanians of more than a religion, and therefore the presence of some sermons and some religious terminologies.

Denial of Islam and atheism for a period of 45 years.

"In terms of Islamic lexicon (Arabic and Persian), it entered in the Albanian language through the Turkish language (as a mediated language) and directly from the Arabic language, especially from the recognition and translation of the Arabic-Islamic literature from the Albanian ulama."3

In this paper, we will try to create a complete picture of the use and misuse of this terminology in chronological sequence. For this, we have observed how this terminology is presented in the lexicographic masterpieces of the Albanian language. The paper contains three parts, according to historical stages through which have passed not only its use, but also the documentation of the writings of Islamic terminology and vocabulary of the Albanian language.

\section{Islamic Terminology in the First Documents of the Albanian Written Language (X-VI century) and the First Dictionaries of the Albanian Language (XVII-XIX century)}

First it should be noted that the Albanian language is a language relatively recently documented. Furthermore the first documents of the Albanian language are fully Catholic versions. This is also one of the reasons why Islamic terminology lacks documentation, which, before the document writing, had long since been turned into part of the daily conversational and religious discourse of the Albanians.

- Dictionary of Franc Bardhi (1635). In this Glossary, the number of Turkishness is not too small, but among the 73 Turkishness noted by Bardhi, only one belongs to Islamic terminology:

- kurban / kurban 4

- Bogdani's work (1685). In this work there are more Turkish-Oriental words, about 94. Bogdani's characteristic is the considerably use of the Islamic religious terminology: dervish, imam, bajram, sacrifice etc. ${ }^{5}$

- In the Da Lecce Dictionary (1702) out of 1700 words, about 376 of them belong to the Turkish-Oriental source. In this Glossary there are some words that belong to the Islamic lexicon: dervish, imam, bajram, kurban, Qaba ${ }^{6}$ etc.

- In the Albanian-Greek dictionary of the folklore collection "Bëleta shqypëtare" of Thimi Mitko (1878) consisting of 1000 words, 505 words are found to be orientalisms and Turkishness. This Dictionary summarizes mainly the South Albanian dialect. From the Turkish-Oriental borrowings, about 48 words belong to the Islamic terminology, such as: hoxhë, bajram, din, dua, gjynah, hajmali, hata, hyri, iman, inqar, jezit, kimet, kësmet, kurban, lanet, lugat, melaiqe, nijet, ogur, pejgamber, qamet, rahmet, selamet, sulltannevruz, shejtan, sheriat, xhenet, xhehenem, xhind, insan, hakikat, shejtan, din, harametj.

- "The Rii Fialuer of Shcypes" of the "Union" society (1908). The Union society was founded in 1899, giving a major contribution to the publication of books in Albanian language with the Latin alphabet, not only with religious character, but also academic, cultural and linguistic. This dictionary is among the most important works of our lexicography and as Jup Kastrati finds in the "History of Albanian grammar", is one of the best in Albanian lexicography until the publication of the Vocabulary of the Institute of Science (1954).

\footnotetext{
2 Isa Bajçinca, "Problems of religious terminology and language culture." the Islamic terminology, the Academy of Sciences and Arts of Kosovo, Pristina, 2006, p. 117.

${ }^{3}$ Mehdi Polisi, The Islamic Lexicon integral part of the Albanian vocabulary, terminology Islamic Academy of Sciences and Arts of Kosovo, Pristina, 2006, p. 84.

4 Lindita Xhanari (Latif), Turkishness and their semantics Albanian dictionaries, Tirana 2012.

${ }^{5}$ Lindita Xhanari (Latif), Turkishness and their semantics Albanian dictionaries, Tirana 2012.

${ }^{6}$ Lindita Xhanari (Latif), Turkishness and their semantics Albanian dictionaries, Tirana 2012.

7Lindita Xhanari (Latifi), Turqizmat dhe semantika e tyre në Fjalorët e shqipes, Tiranë 2012.
} 
The dictionary has 13,798 words and their spelling and grammar is based on Shkodra dialects. For our study purposes, this dictionary is of crucial importance, since in contrast to Thimi Mitko's vocabulary that conveys mainly words from the South Albania, it allows us to study Turkisms and Orientalism, together with the Islamic terminology, even in the North Albanian dialects. On the other hand, designed to be a dictionary, it features a large variety of linguistic phenomena and linguistic developments in the field of borrowings as well. In this dictionary there are about 1,675 orientalisms and Turkishness. Among them are about 131 words that belong to Islam, which indicates that this lexicon was an integral part of the Albanian language and was used broadly, e.g.: hoxhë, bajram, mevlud, din, nevruz, dua, gjynah, terikat, hajmali, hata, hyri, iman, inqar, jezit, kimet, kësmet, kurban, lanet, lugat, melaiqe, nijet, ogur, pejgamber, qamet, myezin, myfti, kalif, minare, vakëf, rahmet, taç, tespihe, selamet, sulltannevruz, shejtan, sheriat, xhenet, xhehenem, xhind, namaz, abdest, zeqat, hadis, haxh, ajet, dua, myslyman, minare, kuran, qitap, imam, sure, namaz, muhib, taksirat, minare, ramazan, vaz, xhemat, zeqat, sadaka, mafil, bismilah, suni, tasdik, xhebrail, mynafik, miraxh, muhammed, qamet, inqar, islam, azab, allah ${ }^{8}$

\section{Islamic Terminology in the Dictionaries of the Communist Period (1944-1991)}

For historical reasons known to all of us, the Albanian nation for about a century had been divided among several nations. This division, with negative consequences in many respects, unquestionably influenced the field of Oriental studies and the one of the Islamic terminology.

It is worthwhile to mention the macabre fact of the monstrous denial of religion and return to a godless, atheistic communist regime of the majority of the Albanians in the Balkans. This painful historical fact had consequences for the science of the oriental studies, as well. Minimally, over 45 years of atheistic regime, all madrasahs were eliminated and the University of Tirana, who remains among most qualitative universities of Albania, never allowed the opening of oriental studies, namely the proper branches of Turkish and Arabic, theological studies of Islam, etc., which would have also been the core of the development of scientific thought in oriental studies.

This political, moral, social, scientific stalemate etc, (call it as you want, as we can put tens of epithets to this phenomenon), resulted in the distancing of linguistic and philosophical science of the Albanians, from the Ethnic Albanians remained outside national borders. The few remaining Albanian scholars were persecuted in their studies. It is noteworthy to mention the bitter fact of the publication of the work of T. Dizdari, many years after his death, from a foreign foundation, not by the Academy of Sciences and Institute of Albanology, which even after communism did not stand up to the responsibility to meet the needs of the science, at the meantime it should have had been an honor to publish his work at the time it was written. Here are also included those scholars who were forced to adapt to the system silently, without resisting pressure, such as the group of the so called researchers who degraded the study of ancient manuscripts of the Albanian language with Arabic alphabet, as worthless and undesirable literature, labeling it as a creation of drunkards, voluptuaries, taverns etc. Briefly, the Orientalistic adopted the status of the "forbidden fruit", by the touching of which you would be burned or disfigured as a scholar and as a man, emerging from oneself and writing the opposite of scientific beliefs, finishing as a prey of the atheist morality.

All these have created a vacuum that even now, while there is a Turkish branch of the University of Tirana since 1996-1997, the oriental studies are not only are unsupported, but also restrained in their developments. This is the main reason that rightfully Prof. Dr. Mehdi Polisi states:

"Because of the political and ideological circumstances within the Albanian territory, the Islamic vocabulary for a certain time (the communist period) has been declining, it has been used with great reserve; and instead the Albanian word is used, that due to the specificity, in no way can cover its meaning; and then it is not represented in the Albanian language dictionaries, even when it is represented, it is given the ideological coloration and, what is worse, explained in a subjective, unscientific and unprofessional manner, missing the right attitude"9

Since the beginning of the Communist regime, due to the atheist ideology it represented, a special allergy of the Islamic terminology was acquired. This was reflected in the language campaigns for cleaning the Albanian Vocabulary from the Islamic terminology. In all the dictionaries of this period, especially those designed by the Institute of Albanology after 1970, thus, after the dictatorial state had destroyed the mosques, Tekke, and madrasas all over Albania and after having killed, jailed and deported all the imams and mullahs, the state began fighting the religious terminology, first in books and dictionaries, and then to the Albanian mentality. This vacuum had some devastating consequences and stages:

\footnotetext{
${ }^{8}$ Lindita Xhanari (Latifi), Turqizmat dhe semantika e tyre në Fjalorët e shqipes, Tiranë 2012.

${ }^{9}$ Mehdi Polisi, the Islamic Lexicon integral part of the Albanian vocabulary, terminology Islamic Academy of Sciences and Arts of Kosovo, Pristina, 2006, p. 84.
} 
- First, the Islamic terminology in the Albanian dictionaries began to evaporate. (This became immediately apparent, especially in dictionaries of 1981, 1982, 1985). This phenomenon was not isolated only in the Albanian Explanatory dictionaries, but also in the dictionaries with two or more languages, dictionaries for children etc. ${ }^{10}$ Whenever began the campaigns of collection of words for the draft of comprehensive dictionary, especially after the Orthography Congress of the Albanian Language (1972), the Islamic terminology was avoided and eliminated purposely. Its users were called reactionaries and enemies, and their families were followed by the curse of killing and incarceration.

- Second, a part of Islamic terminology, which was well known by the Albanian Muslims started to be replaced with synonymous words from the Albanian language, and therefore the real meaning of them got distorted and misunderstood. Here we are introducing three examples, just for illustration, because the monstrous travesty made to Islamic terminology does not deserve to be written and contaminate any paper:

$>$ Qur'an (according to the explanation in the Vocabulary of 1984) - "The book that contains the dogmas of the Muslim religion and various mythical legends"

$>$ Kurban (according to the explanation in the Vocabulary 1984) "cattle slaughtered when you start building a house, allegedly to bring prosper"

$>$ Islam (according to the explanation in the Vocabulary 1984) - "Religion that according to the legend was created in VII century by Muhammad and that spread and protects the Kuran dogmas "11

$>$ Third, and what constitutes the biggest fault, the Islamic terminology in those vocabularies started to be explained based on atheistic communist ideology, and was transformed to the disparagement of mockery of official posts of Islamic denominations, Kuran or Islamic religious holidays.

Fortunately, the opposite has happened to the Albanians that are residing outside of Albania, like in Kosovo and Macedonia. Despite the difficulties of another aspect, already nationalistic, these scholars, for several reasons asses as important the following:

- Freedom of the Islam religion.

- Education in Madrasah.

- Education in Oriental branches in Turkey, Belgrade or in Arab countries.

- Existence of Oriental Branches for a long time, etc.

They have about 30-40 years that successfully handle the burden of Albanian Oriental Studies. These studies appeared in many different forms and in the process of continuous evolution. It is worthy of mentioning the contributions of renowned professors such as proffesor Polis starting with the doctoral thesis of Orientalism in Macedonian Albanian dialects and continuing with the transcripts of the work of Sami Frasheri and also with the scientific contributions on issues of Islamic terminology. What also needs to be mentioned is the voluminous work done by Prof. Memishaj for developing a large Arabic-Albanian vocabulary, the commendable work that Prof.. A. Ismaili has made with Logos publishing house, in the publication and dissemination of Islamic literature, and many other such contributions.

\section{Islamic Terminology in Albanian Dictionaries after the Constitution of Democracy (1992-2013)}

After 1992, due to new political and social developments, especially because of the freedom of religion, the situation began to change and of course the attitude towards Islamic terminology appeared totally different. Nowadays a large number of words have entered such as: ahiret, ajet, Allah, arasat, azab, azrail, din, exhel, gjynah, hair, hallall, haram, hyri, iman, islam, jahudi, kader, kaur, kijamet, Kuran, melaiqe, Muhammed, mysliman, Pejgamber, qafir, qamet, qitap, syni, xhebrail, xhehenem, xhenet, aksham, amin, Bajram, Bismilah, dua, elham, ezan, hafiz, hatib, Hoxhe, ibadet, iqindi, Kurban, Mevlud, namaz, minare, namazgjah, Qabe, Ramazan, sabah, sadaka, saf, salat, sarek, sexhade, sofa, sure, syfyr, teqe, vaiz, vakt, vaz, xhami, xhemat, xhuma, iftar, zeqat ect.

A good part of them are included in the 2006 Albanian language Dictionary. About 300 words of the Islamic terminology are used daily in mass. However there is still much to be done. Now we are faced with other problems:

$>$ First, we have the freedom to use, but still have difficulty explaining the terminology in explanatory dictionaries. Often there are attempts to translate the Islamic terminology in the Albanian language, but in many cases it has resulted unsuccessful. "Indeed, Islam as a religion, but also the Islamic sciences, because

${ }^{10}$ Ramiz Zekaj, "Islamic terminology in Albanian language dictionaries," Islamic terminology, the Academy of Sciences and Arts of Kosovo, Pristina, 2006, p. 53.

${ }^{11}$ Ramiz Zekaj, "Islamic terminology in Albanian language dictionaries," Islamic terminology, the Academy of Sciences and Arts of Kosovo, Pristina, 2006, p. 55. 
of their features and specifications has its own terminology, different from any other terminology. And, it is only that one that is able to express messages of the Islamic truth and bring the man to it. It would be simplistic but wrong to say that the Islamic terminology is Arab terminology, Turkish, Persian or a national language, although it is mostly Arabic etymology, in reality it is adopted as the Islamic terminology, and as such, it is embraced around the world through Islam, while not excluding any local specifications."12

$>$ Second, since Albanians, for known historical reasons, are spread in several Balkan countries, there is a need to unify the Islamic terminology in all variants of Albanian spoken by Albanians, wherever they are. "It is an urgent need that the Albanian literature have a unique Islamic terminology respecting the specificities of the resources of the Islamic religion, to rely on sources of Islam, the Qur'an and the Islamic tradition"13

$>$ Third, due to the existence of several religions in Albania, there is a risk of the unity of the Islamic terminology with the terminology of other religions in the explanatory dictionaries of the Albanian language. This initially requires urgent drafting of a detailed Vocabulary of the Islamic terminology in the Albanian language and then the cooperation among Islamic theologians and Albanians linguists, including the precise meanings of this terminology in Albanian explanatory dictionaries. The scholars of Madrasahs' and Islamic faculties may help on this. "The arrival of a new generation educated in Madrasahs and Islamic Faculties has made possible that oral and written religious recognize qualitative increase of expression and a trend and effort for its development and consolidation."14

\section{Conclusions}

This lexical wealth should be an integral part of the Albanian dictionaries, having acquired the status of an important lexical fund, which belongs to the daily discourse, of the most of the Albanians in the Balkans. "The Albanian language has shown that it has the possibility to realize the spiritual and material demands of the Albanians, and that among the ancient times has proven that there are opportunities to bring the divine world closer to the believers, not only with its potential, but also with the tendency for assimilation, modification and the adaptation of the foreign linguistic material"15

\section{References}

Banguolu, T. (1990). Türkçenin grameri, Ankara.

Boretzky, N. ( 1975). Der Türkische Einfluss auf das Albanische.

Boretzky, N. ( 1981). Sur la substitution des noms de profesion d'origine turque en albanais, Canier Balkanique, 2.

Çabej, E. (1975). For a chronological distribution of Turkish borrowings in Albanian language, SF ,1.

Demiraj, Sh. (2004). Balkan Linguistics, Tirana.

Dizdari, T. ( 2005). Dictionary of Orientalisms, Tirana Dictionary of Modern Albanian Language, Tirana, 1980. Dictionary of Modern Albanian Language, Tirana, 1954. Dictionary of synonymy of the Albanian language, Tirana, 2005.

Ismaji, R. (2000) Old texts , Peja.

Karaagaç, G. ( 2008). Türkçe verintiler Sozlügü, Ankara.

Kazazis, K. (1969). The status of Turkisms in the Present-Day Balkan Languages, Aspects of the Balkans. Continuity and Change, International Balkan Conference.

Kostallari, A.(1978). Entrance of Turkisms in Albanian language during XVII-XVIII centuries", Albanological studies, SSHF, Prishtina .

Krajni, A.(1965). Presence of Turkisims in Albanian language and efforts for their replacement, SF, 1.

Latifi, L. (2006). Turkish borrowings in Albanian language compared to other Balkan languages, Tirana.

Mandala, M., II Dittionario (1702) di F. M. Da Lecce e i turchismi nell'albanese (XVII-XVIII), Albanica 10

Meyer, G. (1891). Etymologisches Wörterbuch der albanische Sprache, Strasburg.

Miklosich, F., Die Türkischen elemente in den südost-und osteuropaischen sprachen (V.I-II), Wien, 1884-1890.

Reinkowski, M. (2002), Zum Status der Turzismen in den sprachen südosteuropa.

Samara, M. (1995). Lexical-semantics of Turkisms in the Albanian Language, SF, 1-4.

12 Qazim Kazimi, "Standardization of Islamic terminology, issues that require resolution" Islamic terminology, the Academy of Sciences and Arts of Kosovo, Pristina, 2006, p. 57-58.

${ }^{13}$ Feti Mehdiu, "For a stable Islamic terminology in Albanian" Islamic terminology, the Academy of Sciences and Arts of Kosovo,

Pristina, 2006, p. 39.

${ }^{14}$ Shefkije Islamaj, "Culture language and Islamic religious writings," Islamic terminology, the Academy of Sciences and Arts of Kosovo, Pristina, 2006, p. 105.

${ }^{15}$ Shefkije Islamaj, "Culture language and Islamic religious writings," Islamic terminology, the Academy of Sciences and Arts of Kosovo,

Pristina, 2006, p. 113 
Schütz, I.( 1986.)Traces of Medieval Turkish Languages in Modern Albanian language, International Seminar on Albanian language, literature and culture, Prishtina.

Vajzovip, H. (1999). Orijentalizmi u književnim dhelu- Lingvistipka analiza, Sarajavo.

Xhuvani, A \& Çabej, E. (1962). Suffixes of the Albanian language, Tirana. 